\title{
Some conceptual and grammatical properties of body part metonymies in English and Bosnian
}

\author{
Adisa Imamović \\ Anela Mulahmetović Ibrišimović \\ University of Tuzla
}

\begin{abstract}
The paper deals with metonymies having body parts as source domains in English and Bosnian. According to Cognitive Linguistics standpoint, human cognition is based on bodily functioning. Therefore, we started from the hypothesis that most body part metonymies are very similar across languages and cultures, and share similar properties. The aim of the paper was threefold: first, to examine whether metonymies with body parts as source domains have common grammatical and conceptual properties in English, secondly to examine whether they share the same properties in Bosnian, and thirdly to compare the two languages in this respect. We analysed body part metonymies in terms of some grammatical properties such as the use of singular and plural, specific and generic reference, grammatical recategorisation from count to mass nouns, noun-to-verb conversion, and some conceptual properties such as source-in-target vs. target-in-source metonymies, metonymic chains and combination of metaphor and metonymy. Many common features were found both within the respective languages under consideration and in cross-linguistic analysis. The minor differences found in contrasting the data from the two languages are mainly the result of differences in grammatical systems.
\end{abstract}

Key words: Cognitive Linguistics; metonymy; metonymic chains; body parts; idioms; recategorisation; conversion.

\section{Aim of the Paper}

The aim of the paper is to examine the similarities between metonymies using body parts as the source domain in English and Bosnian respectively, and then to contrast the data obtained from the two languages. We examined grammatical properties of metonymically used nouns denoting body parts, such as the use of singular and plural, specific and generic reference, grammatical recategorisation from count to mass nouns, noun-to-verb conversion, and some conceptual properties such as source-in-target vs. target-in-source metonymies, metonymic chains 
and combination of metaphor and metonymy. We expected to find a lot of similarities both within a single language and crosslinguistically, since functioning of human bodies is the basis for many cognitive processes, including metonymy and metaphor.

\section{Body Part Metonymies}

In this analysis we used the definition of conceptual metonymy as proposed by Radden and Kövecses (1999) whereby "metonymy is a cognitive process in which one conceptual entity, the vehicle, provides mental access to another conceptual entity, the target, within the same domain, or idealized cognitive model (ICM)." (Kövecses, 2002: 150). According to this theory, conceptual metonymy is not merely a figure of speech, but a cognitive mechanism (Lakoff \& Johnson, 1980).

Metonymy not only provides conceptual access to another entity within the same domain, as the definition above states, but also highlights the relevant features of the target entity by making the secondary domain primary. In this way, the information which is the most important for the speaker is foregrounded. In the sentence Proust is difficult to read. the expression 'Proust' refers to the literary work of the famous author. The use of Proust as a source for his literary work as the target foregrounds the author. In this way, the literary work is perceived as being a result of his talent, almost an extension of his personality, while other aspects of the works are backgrounded (Ruiz de Mendoza and Díez, 2002; Barcelona, 2008; Littlemore, 2015). Littlemore (2015) noticed that metonymic highlighting of body parts to refer to persons is a way of depersonalization, whereby a manual worker is reduced to his/her hands as in the example We need a pair of strong hands.

Analysing body part metonymies in English and Bosnian, we find a number of equivalent conceptual metonymies and metonymic expressions across the two languages. This is not surprising having in mind that our cognition is grounded on bodily experiences (Lakoff \& Johnson, 1980), and functioning of our bodies is something we all share: we see using our eyes, hear using our ears, work using our hands, and think using our brains in our heads. Since metonymy is based on association, people from all cultures associate eyes with vision, ears with hearing and hands with working. This is why most languages share the same conceptual metonymies with body parts as source domains. Yet, there are some language-specific and culturally influenced differences. Many studies of body part metonymies (and metaphors) show that the bigger the differences between the cultures and the languages compared, the bigger are the differences in metonymic mappings and expressions (Yu, 2000; Deignan \& Potter, 2004; Radić-Bojanić \& Silaški, 2012; Stanojević, 2013; Zhang et al, 2015). 


\section{Corpus}

The corpus for the study consisted of 203 metonymic expressions in the English language and 272 expressions in Bosnian. English examples used in the analysis were taken from COCA (The Corpus of Contemporary American English). In the absence of Bosnian electronic corpus, Bosnian examples were taken from online editions of daily newspapers Dnevni avaz and Oslobođenje, news portals Klix.ba and TIP.ba, and literary works of several Bosnian authors.

\section{Methodology}

Expressions containing metonymic uses of nouns denoting body parts were collected and analyzed manually. Metonymic mappings were identified based on metonymic taxonomy proposed by Radden \& Kövecses (1999), and Kövecses (2002). Then we analyzed grammatical properties of the metonymically used nouns and other conceptual processes relevant for the analysis, such as double metonymy, metonymic chains, and metonymy within metaphor (Hilpert, 2006; 2007; Brdar, 2007; Goossens, 1990; 1995; 2002; Ruiz de Mendoza \& Díez 2002).

Nouns denoting body parts are often found in metonymically used complex expressions denoting actions, such as SUB-EVENT FOR COMPLEX EVENT (e.g. put a ring on her finger ('marry her'), otvoriti usta ('open one's mouth' for 'start speaking')) or EFFECT FOR CAUSE (her stomach growled ('she was hungry'), shrug one's shoulders ('show indecision or indifference'), ide mu voda na usta ('his mouth waters' for 'he wants to eat something'). Such examples were not taken in consideration in this analysis, since the source domain is not a body part itself, but an action in which the body part is involved.

\section{Analysis}

\subsection{Specific and generic reference}

Although body part nouns can be used both for specific and generic reference, the corpus analysis in English and Bosnian shows that these nouns are much more common in specific reference.

When body part metonymies have generic reference, they always refer to a person:

English:

(1) Not everyone looks at a pretty face and instantly thinks about having an affair. 
(2) At the time I was a broken-spirited nine-year-old in desperate need of a shoulder to cry on.

Bosnian:

(3) Starac je za njega preuredio dvorišnu zgradicu, koja je prije bila kuhinja, ali je sada, kako u kući nema ženske glave, kako se izvalio onaj četvrti direk, ona izgubila svrhu. ['woman's head' = woman]

(4) Krunski svedoci su bili u helikopteru, a mrtva usta ne govore. ['dead mouth' = dead person]

When they have specific reference they can refer to a person, an action or an event:

English:

- a person:

(5) "Is that clear? " Five heads nodded and five serious faces hoped that she meant it.

- action (looking, supervising, speaking)

(6) Vun is so shy she barely speaks. Her eyes drop when I look at her.

(7) Watch your mouth. Why are you cursing on TV?

Bosnian:

- a person

(8) Ali, desilo se i nešto što je promijenilo razmišljanje dobrog dijela glava na prostoru bivše Jugoslavije, ili regiona, kako se to sada zove. ['heads' = persons]

(9) Osam lica zadobilo je povrede, a jedno lice je smrtno stradalo, navodi izvor. ['eight faces' $=$ eight persons]

- action (manual work, supervising, control)

(10) Pomogli su vaučeri da kupimo materijal, ali smo ruke sami plaćali. ['hands' = manual work]

(11) Ekipa Al Jazeere bila je pod budnim okom vodiča, koji su kontrolirali svaki njihov pokret. ['under a wakeful eye' = under supervision]

\subsection{Inflections}

In fixed expressions and idioms we find unexpected use of singular forms of nouns which denote body parts normally found in pairs, such as ear and eye (Moon, 1998: 95), when these nouns are used metonymically. When they are used in literal sense, they are usually used in plural, e.g. open/close one's eyes, have blue/hazel/big eyes, etc. 
- a person

(12) Yes, to the non-Texan eye, it looks like Republican Gov. Rick Perry has slunk home from his last rodeo,...

(13) Helton said. "I'm an untrained eye, but I knew it hurt when I caught it."

- attention

(14) Something moving caught my eye.

- intention

(15) She took several classes during the week with an eye to transferring to a university the following year.

- desire

(16) Besides, she had her eye on a pair of mint green jeans that would be perfect for spring.

- look

(17) He stepped toward me, and my eye instantly fell on the shiny bronze lizard brooch he was wearing on the pocket of his gray T-shirt.

but the plural is also possible in some situations:

(18) One day my eyes fell on one of the photo-postcards a friend occasionally sends us.

We find the same use of singular oko 'eye' in Bosnian when it refers to

- a person

(19) Stil života ovih gorštaka možda se zapadnjačkom oku doima romantičnim, ali život koji su sebi izgradili je težak. ['a western eye' = a person from the West]

(20) A to što su princ Hasan i Abdallah ibn Sabah došli do onih crteža dokazuje da zlo oko ima pristupa i u moje sobe i do mojih bilježaka. ['evil eye' = evil person]

- attention

(21) Džeko je u modi: Dijamant ponovo zapeo za oko Staroj dami. ['caught an eye' = caught the attention of]

- supervising

(22) Njegova majka Sharifa stalno ga drži na oku. ['keeps an eye on him' = supervises him]

(23) Dok se oporavlja pod budnim okom liječnika, pojedini stanovnici njenog sela pričaju potpuno drugačiju priču. ['under the wakeful eye' = under the supervision]

- good perception

(24) Prije nego što sam se počela baviti modelingom, studirala sam dizajn, tako da imam oko za lijepo. ['have an eye for' = have a good perception for] 
(25) Zahuktava se rat između historičara umjetnosti sa istančanim okom i naučnika koji sa jednakom arogancijom torde da su u pravu kad je riječ o utvrdivanju autentičnosti. ['have a sharp eye for' = have a good perception for]

Other examples:

English: singular where typically both members of pairs are involved: give somebody a hand - (applaude) (physical help), a factory hand (manual labour), a hand for woodwork (ability or skill), a heavy foot (manner of walking), set foot on/in (go to a place), have an ear for (ability to hear and judge sounds/to learn music or languages)

Bosnian: ženska ruka ('a woman's hand' = housecleaning work), imati tešku ruku ('have a heavy hand' = be heavy-handed), kročiti nogom $u / n a$ ('set a foot in' = go to a place), imati uho $z a$ ('have an ear for' = ability to hear and judge sounds/to learn music or languages)

\subsection{Countable and mass nouns}

Grammatical recategorisation is often a signal of figurative meaning, whether it is recategorisation from countable to mass nouns as mentioned in Brdar (2007) or recategorisation of proper nouns as common nouns (Barcelona, 2003; Brdar, 2007; Brdar \& Brdar-Szabó, 2007; Berberović, 2009).

Nouns denoting body parts are countable. As noticed by Brdar (2011) many countable nouns often undergo recategorisation and become mass nouns (and vice versa), such as a turkey: some turkey, an oak: some oak. However, such processes are almost non-existent when it comes to nouns denoting body parts.

Some isolated examples of count-mass recategorisation can be found in the register of cuisine. In such cases body parts refer to animal body parts conceptualised as food.

(26) Meltingly tender with just a little game to excite the palate, roast leg of lamb with a simple rub of herbs makes for a superb main course.

Another example is the use of leg in the idiom show some leg. This idiom is colloquial, sometimes used in entertainment magazines meaning 'to expose one's legs to view in order to flirt or to seek attention'.

(27) (Additional reporting by Joshua Rich) Photograph CELEBRITY SKIN The rockeractress shows some leg at the Man on the Moon (with beau Jim Barber, left).

The Bosnian counterpart of this expression pokazati malo kože 'show some skin' is also mainly used in tabloids and entertainment industry, and the countable noun $k o z ̌ a$ 'skin' changed the status from countable to uncountable. Otherwise, this process is very rare in Bosnian, too, when it comes to body part nouns. 


\subsection{Conversion}

Noun-to-verb conversion is dealt with in Dirven (1999), Ruiz de Mendoza \& Pérez Hernández (2001), Ruiz de Mendoza \& Otal (2002) and Buljan (2007) among others.

Noun-to-verb conversion is rare in English with this type of nouns, and not found in Bosnian due to morphological reasons - Bosnian verbs require obligatory verbal inflections.

(28) She looked up once, eyed me, but never quit writing.

(29) As a writer and academic, I had never had to mouth anyone else's opinions or defer to any party line.

(30) I don't have to elbow my way through crowds to chase the tournament leaders from hole to hole.

Also: to hand (to give), to foot it (to dance to music), to leg it (to walk fast or run), to shoulder (to lift or carry someting on your shoulder)

\subsection{Semantic cues}

Since formal (grammatical) signals of metonymy such as grammatical recategorisation and conversion are very uncommon with this type of nouns, metonymic use is commonly signalled by semantic incongurity, usually a verb or an adjective whose meaning clashes with the basic meaning of nouns denoting body parts thus resulting in a paradox.

We can see this in the following English examples:

(31) Plouffe has never lacked the stomach for a political knife fight. (person - lack stomach)

(32) But if she'd broken up with another boyfriend and wanted a sober shoulder to cry on, she needed to look elsewhere. (sober - shoulder)

(33) "An untrained eye would walk past most of the oldest organisms none the wiser, " Sussman says. (untrained - eye)

and Bosnian examples:

(34) Jedna glava hranila je sedmero. (glava - hraniti 'One head fed seven people.' head - feed)

(35) Kako se pretpostavlja, nepoznato lice ili više njih pucalo je u Vujičića u momentu kada je izlazio iz lokala. (lice - pucati '... an unknown face or several of them shot at Vujičić...' face - shoot at)

(36) Ističu da nezaposleno lice umjesto dosadašnje prakse "da ode na biro", danas mora poštovati kućni red, odnosno pozivom na broj lokalnog biroa mora rezervisati termin. (nezaposleno - lice 'They say that an unemployed face...' unemployed - face) 


\subsection{Source-in-target and target-in-source metonymies}

Ruiz de Mendoza and Velasco $(2001,2002)$ make distinction between two types of metonymies based on domain-subdomain relationship. In the first, the source is the subdomain of the target, as in The sax won't come today, where the instrument is the subdomain of the musician (source-in-target metonymies). In the second type, the target is the subdomain of the source as He enjoys Shakespeare, where the literary work is the subdomain of the author (target-in-source metonymies). While source-in-target metonymies work on the basis of domain expansion, the target-insource metonymies are examples of domain reduction. Nouns denoting body parts are predominantly source-in-target metonymies, i. e. a body part typically refers either to the whole person or to an action or another state-of-affairs of which it is part. This can be seen in all the examples give above. Very few examples in our corpus illustrate target-in-source metonymy, for example MOUTH FOR LIPS and HEAD FOR HAIR.

English

(37) A couple of weeks ago, I even had to shave my head.

(38) Men's clothes were shabby brown and gray; ghostlike women covered their heads with dark shawls.

(39) You're on drugs? "She pressed her mouth together.

Bosnian has the same metonymy e.g. sijeda/bijela glava. ('grey/white head' where head stands for hair), obrijati glavu ('shave one's head'), pokriti glavu ('cover one's head').

\subsection{Metonymic chains}

Metonymic chains are metonymies involving multiple conceptual shifts, breaking up "complex conceptual mappings into simple, well-motivated mappings with a strong experiential basis" (Hilpert, 2007: 80). Brdar \& Brdar-Szabó (2007), use the term metonymic tiers, which includes both metonymic chains and interaction of a metonymy and a metaphor. Body part metonymies are very often used in chains of two or three. Double metonymies are also often combined with metaphors, expecially THOUGHTS/EMOTIONS/ ACTIONS ARE OBJECTS:

EYE FOR WATCHING + WATCHING FOR SUPERVISING

English

(40) Trust grew, and then Arieff's follicles, fertilized by Berline, were implanted into Vaina under the watchful eye of Dr. Nayna Patel.

Bosnian

(41) Palestinci su prisiljeni živjeti pored izraelskih doseljenika, i to pod budnim okom izraelskih vojnika. ('under a wakeful eye of')

EYE FOR WATCHING + WATCHING FOR ATTENTION 
English

(42) Something moving caught my eye.

(43) Tahoe is already drawing the eye of smaller yet equally vibrant Colorado developers.

Bosnian

(44) Nije lako pričati kada vas svi drže na oku. (lit. 'everybody holds you on eye' = 'everybody keeps an eye on you')

EYE FOR WATCHING + WATCHING FOR ATTENTION + ATTENTION FOR DESIRE

English

(45) He said he had his eye on a townhouse and the broker saw no trouble getting together the financing.

Bosnian

(46) Tri tešanjska privrednika bacila oko na imovinu. (lit. 'Three businessmen from Tešanj threw an eye on the property.' = "Three businessmen from Tešanj had their eye on the property.')

Another example in Bosnian: sijeda/bijela glava ('grey/white head': GREY HEAD FOR GREY HAIR + GREY HAIR FOR OLD PERSON (EFFECT FOR CAUSE)).

\subsection{Metonymies combined with metaphors}

Body part metonymies are often combined with metaphors. Below we have examples of metonymy within metaphor, where a metonymically used expression is embedded within a metaphorical expression (Goossens, 1995). In the expresssions below, hand metonymically stands for holding, and is then combined with the metaphors POSSESSION IS HOLDING and CONTROL IS HOLDING.

HAND FOR HOLDING + POSSESSION IS HOLDING

English:

(47) There is plenty of money out there to pay for college costs, but most of it is in private hands.

(48) By the end of the day, about 570 million shares had changed hands, a huge trading volume for any company.

Bosnian:

(49) Dodgersi, koji su najuspješnija ekipa u historiji bejzbola sa šest osvojenih titula, ali posljednjom još davne 1988. godine, preći će u ruke novih vlasnika do kraja aprila, jer transakciju mora odobriti sud, pošto je klub zvanično u stečaju. ('move into the hands')

(50) Analitičari procjenjuju da je više od polovine nekretnina otišlo u ruke stranih kupaca, najviše iz Eurozone. ('went into the hands') 


\section{HAND FOR HOLDING + CONTROL IS HOLDING}

English:

(51) To prevent the B-25s' top secret and highly accurate Norden bombsights from falling into enemy hands, they were replaced by makeshift sights costing 20 cents each.

(52) Judge James Daniel said the decision was "out of my hands".

Bosnian

(53) Srebrenica je pala u ruke vojske Republike Srpske pod komandom Ratka Mladića u julu 1995. ('fell in the hands of')

(54) Marc Wilmots je kao neiskusan trener 2012. godine dobio u ruke neizbrušeni dragulj - belgijsku reprezentaciju. ('got $\mathrm{x}$ in his hands')

Similarly, in the examples below, the lexeme eye is first used metonymically for the action of looking/watching, and in the second stage this metonymy is combined with the metaphor ACTIONS ARE OBJECTS.

BODY PARTS FOR ACTIONS + EVENTS/ ACTIONS ARE OBJECTS (EYES FOR LOOKING + ACTIONS ARE OBJECTS)

English:

(55) Faint tendrils of steam still rose from the cooling bodies, the cut edges of the hides rimmed in frost. Then my eyes fell to the ground.

(56) Vun is so shy she barely speaks. Her eyes drop when I look at her.

(57) But I didn't go to her. I couldn't take my eyes off the old woman and her son.

Bosnian

(58) Nije mogao skinuti oči s nje - Kim pokazala i previše. ('he could not take his eyes off of her')

(59) Naprosto se nisam usuđivao da podignem oči kao da ću ugledati Bog zna kakvu nakazu. ('I didn't dare lift my eyes.')

In our corpus we found many expressions which show this type of interaction.

\subsection{Idioms and fixed expressions}

Body part metonymies are very often used in idioms and fixed expressions especially when they are combined with metaphors, as in close one's eyes to something (refusing to know: EYE FOR SEEING + KNOWING IS SEEING), have a hand in something (help something happen (HAND FOR HELP + EVENTS/ ACTIONS ARE CONTAINERS) or in Bosnian izgubiti glavu ('lose one's head' HEAD FOR CONTROL + CONTROL IS AN OBJECT) and bacati prašinu u oči ('to throw dust in one's eyes' = 'to deceive someone' EYES FOR SEEING + KNOWING IS SEEING) 


\section{Conclusion}

Our analysis shows that body part metonymies share common properties within each respective language, and that there are also a lot of similarities in the conceptual mappings, metonymic expressions and grammatical behaviour between the two languages. These results were expected, because the examples come from similar cultures and the languages are not very different.

The biggest difference found in the contrastive analysis is the possibility of noun-to-verb conversion in English using the metonymy OBJECT (BODY PART) USED IN THE ACTION FOR THE ACTION, while Bosnian grammatical system does not allow for noun-to-verb conversion.

In all other aspects, body part metonymies in the two languages shared the same properties. Their use is mainly for specific reference, while generic reference is limited only to the metonymy BODY PART FOR PERSON. Body part metonyms are countable nouns and they do not systematically undergo recategorisation from countable to mass nouns, like the examples of some items used for food or building material (e.g. a turkey: some turkey, an oak: some oak). Moreover, both languages use an uncommon singular form of nouns referring to body parts normally found in pairs, such as eyes and ears. Conceptually, they are predominantly source-intarget metonymies, reducing the domain of a person, its actions, emotions and other related domains to the subdomain of a body part relevant for the context. In both languages body part metonymies are very frequently found in double metonymies or metonymic chains, and in combination of metonymies and metaphors, and these combinations are often used in idioms and fixed expressions.

Since our corpus was very limited, we listed only the prevailing trends without providing the exact figures. However, we believe that this paper can point to some directions for a much larger corpus analysis which could yield more accurate statistical results.

\section{References:}

Barcelona, Antonio (2003). Names: A metonymic 'return ticket' in five languages. Jezikoslovlje 4.1: 11-41

Barcelona, Antonio (2008). Metonymy is not just a lexical phenomenon: On the operation of metonymy in grammar and discourse. Alm-Arvius, Christina, Nils-Lennart Johannesson, David C. Minugh, eds. Selected papers from the Stockholm 2008 Metaphor Festival. Stockholm: Stockholm UP, 1-40.

Berberović, Sanja (2009). Would you like to be the Michael Jordan of linguistics? Construction of figurative meaning of personal names. Brdar, Mario, Marija Omazić, Višnja Pavičić-Takač, eds. Cognitive Approaches to English: Fundamental, Methodological Interdisciplinary and Applied Aspects. Newcastle: Cambridge Scholars Publishing, 173-201. 
Brdar, Mario (2007). Metonymy in Grammar: Towards Motivating Extensions of Grammatical Categories and Constructions. Osijek: Filozofski fakultet.

Brdar, Mario (2015). Metonymic chains and synonymy. Fluminensia 27.2: 83-101.

Brdar, Mario, Rita Brdar-Szabó (2007). When Zidane is not simply Zidane, and Bill Gates is not just Bill Gates: Or, Some thoughts on online construction of metaphtonymic meanings of proper names. Radden, Günter, Klaus-Michael Köpcke, Thomas Berg, Peter Siemund, eds. Aspects of Meaning Construction. Amsterdam: John Benjamins, 125-142.

Buljan, Gabrijela (2009). The meaning of English conversions: Quirky or not? Brdar, Mario, Marija Omazić, Višnja Pavičić-Takač, eds. Cognitive Approaches to English: Fundamental, Methodological Interdisciplinary and Applied Aspects. Newcastle: Cambridge Scholars Publishing, 99-122

Deignan, Alice, Liz Potter (2004). A corpus study of metaphors and metonyms in English and Italian. Journal of Pragmatics 36: 1231-1252.

Dirven, René (1999). Conversion as a conceptual metonymy of event schemata. Panther, Klaus-Uwe, Radden Günter, eds. Metonymy in Language and Thought. Amsterdam: John Benjamins, 275-287.

Goossens, Louis (1990). Metaphtonymy: the interaction of metaphor and metonymy in expressions for linguistic action. Cognitive Linguistics 1: 323-340

Goossens, Louis (1995). Metaphtonymy: the interaction of metaphor and metonymy in figurative expressions for linguistic action. Goossens, Louis, Paul Pauwels, Brygida Rudzka-Ostyn, Anne-Marie Simon-Vandenbergen, Johan Vanparys, eds. By Word of Mouth: Metaphor, Metonymy and Linguistic Action in a Cognitive Context. Amsterdam: John Benjamins, 159-174.

Goosens, Louis (2002). Metaphtonomy: The interaction of metaphor and metonymy in expression for linguist action. Dirven, René, Ralf Pörings, eds. Metaphor and Metonymy in Comparison and Contrast. Berlin and New York: Mouton de Gruyter, 349-378.

Hilpert, Martin (2006). Keeping an eye on the data: Metonymies and their patterns. Stefanowitsch, Anatol, Stefan Th. Gries, eds. Corpus-Based Approaches to Metaphor and Metonymy. Berlin and New York: Mouton de Gruyter, 123- 151.

Hilpert, Martin (2007). Chained metonymies in lexicon and grammar: A cross-linguistic perspective on body-part terms. Radden, Günter, Klaus-Michael Köpcke, Thomas Berg, Peter Siemund, eds. Aspects of Meaning Construction. Amsterdam: John Benjamins, 77-98.

Imamović, Adisa (2011). Metonimijski procesi u nominalizaciji: Kognitivno-lingvistička analiza. Tuzla: OFF-SET Tuzla.

Kövecses, Zoltan (2002). Metaphor: A Practical Introduction. New York: Oxford University Press.

Lakoff, George, Mark Johnson (1980). Metaphors We Live By. Chicago and London: The Chicago University Press.

Littlemore, Jeanette (2015). Metonymy: Hidden Shortcuts in Language, Thought and Communication. Cambridge: Cambridge University Press.

Moon, Rosamund (1998). Fixed Expressions and Idioms in English: A Corpus-Based Approach. Oxford: Clarendon.

Mulahmetović Ibrišimović, Anela (2015). Metonymic Uses of Body Parts in English and Bosnian. Unpublished M. A. thesis. Tuzla University 
Radden, Günter, Zoltan Kövecses. (1999). Towards a theory of metonymy. Panther, KlausUwe, Günter Radden, eds. Metonymy in Language and Thought. Amsterdam: John Benjamins, 17-59.

Radić-Bojanić, Biljana, Nadežda Silaški (2012). Metaphoric and metonymic conceptualizations of the head - a dictionary-based contrastive analysis of English and Serbian. Facta Universitatis, Series: Linguistics and Literature 10.1: 29-39.

Ruiz de Mendoza Ibáñez, Francisco José, Lorena Pérez Hernández (2001). Metonymy and the grammar: Motivation, constraints and interaction. Language and Communication 21.4: 321-357.

Ruiz de Mendoza Ibañez, Francisco J., Olga I. Diéz Velasco (2001). High-level metonymies and linguistic structure. http://sincronia.cucsh.udg.mx/metonymy.htm

Ruiz de Mendoza Ibañez, Francisco J., Olga I. Diéz Velasco (2002). Patterns of conceptual interaction. Dirven, René, Ralf Pörings, eds. Metaphor and Metonymy in Comparison and Contrast. Berlin and New York: Mouton de Gruyter, 501-46.

Ruiz de Mendoza Ibáñez, Francisco José, \& José Luis Otal Campo (2002). Metonymy, Grammar and Communication. Albolote: Comares.

Stanojević, Mateusz-Milan (2013). Konceptualna metafora: temeljni pojmovi, teorijski pristupi i metode. Zagreb: Srednja Europa

$\mathrm{Yu}$, Ning (2000). Figurative uses of finger and palm in Chinese and English. Metaphor and Symbol 15.3: 159-75

Zhang ,Weiwei, Dirk Speelman, Dirk Geeraerts (2015). Cross-linguistic variation in metonymies for PERSON: A Chinese-English contrastive study. Review of Cognitive Linguistics 13.1: 220-256

\section{Corpus:}

http://corpus.byu.edu/coca/

http://www.klix.ba/

http://www.tip.ba/

http://www.oslobodjenje.ba/

http://www.avaz.ba/

\section{List of literary works used as corpus:}

Čolaković, Enver (1989). Legenda o Ali-paši. Zagreb: Islamska zajednica Zagreb.

Ćopić, Branko (1979). Orlovi rano lete. Zagreb: Mladost

Džamonja, Dario (2003). Priče. Sarajevo: Sarajevo Pressing.

Karahasan, Dževad (1989). Istočni divan. Sarajevo: Svjetlost,

Mulabdić, Edhem (1898). Zeleno busenje. Zagreb: Matica Hrvatska

Selimović, Meša (1966). Derviš i smrt. Sarajevo: Svjetlost

Selimović, Meša (1970). Tvrđava. Sarajevo: Svjetlost

Selimović, Meša (1974). Ostrvo. Beograd: Prosveta

Sušić, Derviš (1984). Veliki vezir: Istorijska drama u dva dijela (šest slika). Sarajevo: Zajednica profesionalnih pozorišta.

\section{Dictionaries:}

Collins COBUILD English Dictionary for Advanced Learners. 2001. HarperCollins Publishers. 
Longman Dictionary of Contemporary English [Online]. http://www.ldoceonline.com/ dictionary/discrepancy.

Macmillan Dictionary [Online]. http://www.macmillandictionary.com/.

Vrgoč, Dalibor, \& Željka Fink Arsovski (2008). Hrvatsko-engleski frazeološki rječnik. Zagreb: Naknada Ljevak.

Authors' addresses:

University of Tuzla

Tihomila Markovića 1

75000 Tuzla

Bosnia and Herzegovina

adisa.imamovic@untz.ba

aimulahmetovic@gmail.com

Received: August 29, 2016

Accepted for publication: September 8, 2016 